\title{
Expansion of urban recreation areas as a factor for human capital renovation
}

\author{
Tatiana Ovsiannikova ${ }^{1, *}$, Mariya Nikolaenko $^{1}$, and Mergesh Chilbakova ${ }^{1}$ \\ ${ }^{1}$ Tomsk State University of Architecture and Building, 2, Solyanaya Sq., 634003 Tomsk, Russia
}

\begin{abstract}
The paper is focused on the development of urban space on the basis of the modern urban development concepts. The role of urban environment in the development of individuals, their physical, intellectual and spiritual potential is described with the use of human capital theory. The City Recreation concept is suggested to be accounted while planning the urban territory development. The role of recreation areas in urban environment is described, classification of urban recreation areas is given. The paper recites the results of a social study devoted to evaluation of satisfaction of typical urban district residents with the number and quality of recreation areas. Recommendations are given on public spaces expansion to provide daily recreation.
\end{abstract}

\section{Introduction}

Human capital becomes one of the main production factors in post-industrial economy. Economic growth of a state and the level of population well-being are largely defined by its accumulated human capital. As Klaus Schwab, the Founder and Executive Chairman of World Economic Forum, said: "The key for the future of any country and any institution lies in the talent, skills and capabilities of its people" [1], "Talent, not capital, will be the key factor linking innovation, competitiveness and growth in the 21 st century" [2]. That is why global scientific community pays close attention to the issue of providing socioeconomic conditions for creation and development of human capital.

One of the consequences of global urbanization processes is concentration of human capital on urban territories. Multiple studies, including those performed by the authors of the paper, show that modern cities become attraction centers both for investment capital and human capital. The most economically developed territories get a strong incentive for economic growth and become ever more successful by attracting investment and human capital. At the same time, territories where human capital flight is observed switch to negative dynamics and become more depressive and stagnant. For that reason, attractiveness of urban areas for human capital becomes the major competitive advantage of the territory in the global labor and capital markets.

Due to the desire to increase the territory attractiveness for human capital local authorities and urban development stakeholders focus local urban policy on an individual. Analysis of theory and practice of urban territories development in various countries

* Corresponding author: tatovs@mail.ru 
showed that the most successful are cities where socio-economic relations "city-person" are based on the modern concepts of urban development, which are "Liveable City", "Creative City", "City of Opportunities" [3]. According to the authors' opinion, these concepts can be complemented by the "Recreation City" concept. This paper is aimed to justify this urban development concept.

\section{Methodology}

Human capital theory has won strong positions in economic science since the second half of the $\mathrm{XX}^{\text {th }}$ century, its authors being awarded with a Nobel Prize. This theory has become a methodological framework for numerous studies on the role of a person as the key development factor for social production. The theory is focused on a person as a source of knowledge, skills and competences. Accumulation of critical mass of human capital is considered as a condition for transit of the national economy from one technological frameworks to another.

Due to complexity and multidimensionality of the Human Capital concept multiple approaches and methodologies are used for its investigation. The majority of national and foreign researchers use investment approach as a basis, which considers assessment of human capital with regard to expenditures on its formation as a key issue. Such expenditures include investments in education, public health, etc. (Th. Schultz, 1963, 1971; G. Becker, 1975; R. Kapelyushnikov, 1993, S. Dyatlov, 1993, etc.). Later on, the reproduction approach was formed within the human capital theory, according to which human capital was considered throughout its whole life cycle. During this time, human capital undergoes the stages of its creation (formation), distribution, exchange and use. This is reflected in The Human Capital Reports where Human Capital Index is evaluated with the account of not only the stage of human capital formation, i.e. learning, but also the stage of use of human capital, i.e. employment $[1,2]$.

Human capital is a long-term resource; in the process of socio-economic activity this capital is depreciated, loses its quality and deserves renovation, just like physical capital. Reproduction approach to human capital study allows introducing the notion of human capital renovation. This category denotes the process of renovation and recovery of physical, intellectual and spiritual potential of a human which was spent while performing socio-economic activities. Unlike the renovation of fixed capital which is performed discretely and periodically throughout the life cycle of fixed assets, human capital renovation shall be performed almost permanently throughout the whole stage of its socioeconomic activity.

Human capital being non-material wealth of a person, and collectively representing nonmaterial wealth of a city, region and state, requires material assets for its formation, maintenance and renovation. These assets primarily include material costs for creation of high-quality living environment which provides formation of high-quality human capital and its renovation.

The great impact of living environment on formation of human personality, intellectual, physical and spiritual potential, as well as on human identity, is accepted by many researchers from various fields, including philosophy, sociology, psychology, architecture, urban planning, economics, etc. The special term of "place-identity" which denotes a substructure of self-identity, much like gender and social class, and is comprised of perceptions and comprehensions regarding the environment" has become almost interdisciplinary [4].

Thus, competitiveness of a city in global markets greatly depends on the level of conditions the city can provide for formation and renovation of human capital. 
This function within the city is performed by public recreation areas meant for recovery and development of physical, intellectual and spiritual assets of a person spent in the process of his socio-economic activity. As a rule, such areas are multifunctional and perform communicative, educational, information, developing, entertaining, sportive, recreational, emotional, aesthetic, and other functions which contribute to human capital recovery. The importance of this task in Russia is acknowledged on the governmental level. The priority project "Formation of the comfortable urban environment" [5] was launched, its purpose being creation of new or improvement of the existing public spaces, including public recreation areas and courtyard spaces.

In this regard, investigation of the issue of sufficiency, availability and appropriateness of public recreation areas in urban environment is an important interdisciplinary task for economists, sociologists, urban planners, urban designers.

Methodologies for studying and understanding such problems usually involve qualitative techniques, such as interviewing, participant observation and mapping. Such studies are presented in works $[6,7]$. This research was performed with the application of traditional methodologies, along with the method of correlation analysis and mapping.

\section{Data \& Research}

The previous research demonstrate close correlation between the level of human development and the level of urban environment development. Thus, correlation analysis performed by the authors of this paper with the use of data presented in $[1,8]$ show that a definite relation exists between the City Prosperity Index (CPI) and the Human Capital Index (HCI) (Fig.1).

Obviously, this relation has a reciprocal nature, which means that a successful city creates a successful personality, and a person with high potential makes a contribution to the city prosperity and development. However, the city shall not only provide the opportunity for a person to function as a production factor, but also provide the renovation opportunities, since this directly affects the human capital efficiency.

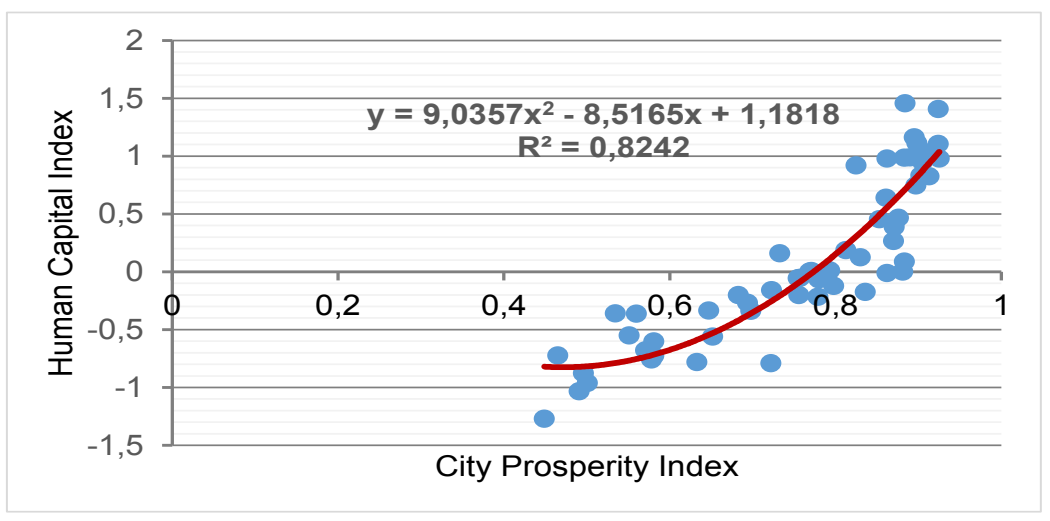

Fig. 1. The relation between City Prosperity Index and the Human Capital Index (performed by the authors).

As already mentioned, renovation is provided by recreation areas in the urban environment. Recreation as a specific type of human activity is performed with certain intervals - daily, weekly, annually, etc. Consequently, urban environment shall include public recreation areas of different types (Table 1). 
Table 1. Classification of public recreation areas.

\begin{tabular}{|c|c|c|c|}
\hline $\begin{array}{l}\text { Type of public } \\
\text { recreation area }\end{array}$ & Type of recreation activity & Frequency & $\begin{array}{l}\text { Elements of public } \\
\text { recreation areas }\end{array}$ \\
\hline $\begin{array}{l}\text { Micro-area } \\
\text { (courtyard) }\end{array}$ & $\begin{array}{c}\text { Recreation } \\
\text { Communication }\end{array}$ & Daily & $\begin{array}{l}\text { Playgrounds and sports } \\
\text { grounds in courtyards }\end{array}$ \\
\hline $\begin{array}{c}\text { Local } \\
\text { (quarter, district) }\end{array}$ & $\begin{array}{c}\text { Recreation } \\
\text { Communication } \\
\text { Sports }\end{array}$ & $\begin{array}{l}\text { Weekly } \\
\text { Monthly }\end{array}$ & $\begin{array}{l}\text { Parks, playgrounds and } \\
\text { sports grounds }\end{array}$ \\
\hline City & $\begin{array}{c}\text { Recreation } \\
\text { Communication } \\
\text { Sports } \\
\text { Entertainment } \\
\text { Education }\end{array}$ & $\begin{array}{l}\text { Weekly } \\
\text { Monthly }\end{array}$ & $\begin{array}{l}\text { Parks, squares, } \\
\text { pavements, } \\
\text { embankment, rest } \\
\text { places in business } \\
\text { centers, stadiums, } \\
\text { groves, water objects. }\end{array}$ \\
\hline $\begin{array}{l}\text { Meso-area } \\
\text { (regional) }\end{array}$ & $\begin{array}{c}\text { Recreation } \\
\text { Communication } \\
\text { Sports } \\
\text { Entertainment } \\
\text { Education } \\
\text { Rehabilitation }\end{array}$ & $\begin{array}{l}\text { Monthly } \\
\text { Annually }\end{array}$ & $\begin{array}{l}\text { Parks, multifunctional } \\
\text { complexes (sports, } \\
\text { tourism, culture) }\end{array}$ \\
\hline $\begin{array}{l}\text { Macro-area } \\
\text { (national) }\end{array}$ & $\begin{array}{c}\text { Recreation } \\
\text { Rehabilitation } \\
\text { Communication } \\
\text { Education } \\
\text { Entertainment } \\
\text { Aesthetic pleasure }\end{array}$ & $\begin{array}{l}\text { Periodically, } \\
\text { once in several } \\
\text { years }\end{array}$ & $\begin{array}{l}\text { National parks, national } \\
\text { cultural complexes, } \\
\text { national rehabilitation } \\
\text { centers }\end{array}$ \\
\hline
\end{tabular}

The authors of the study surveyed residents of one of Tomsk districts (Russia). The purpose of the survey was to analyze provision of urban environment with public recreation areas, to assess the quality of recreation areas and sufficiency of functions they perform. Tomsk represent a typical Russian city, its population is 594 thousand citizens [9]. One of special features of Tomsk is its University City status, which results in a high share of young people in its demographic structure. This fact affected the structure of respondents, the majority of whom are represented by young people aged between 21 and 30. Opinion polling and remote polling methods, the latter with the help of Survio software (https://www.survio.com/ru), were used in the study. Around 400 people were surveyed within the study.

\section{Results}

Based on the survey results the authors obtained the data that enabled to analyze the quality and quantity of public recreation areas in Tomsk city. Some of the results are given in Figures 2-5 and Tables 2-3. 


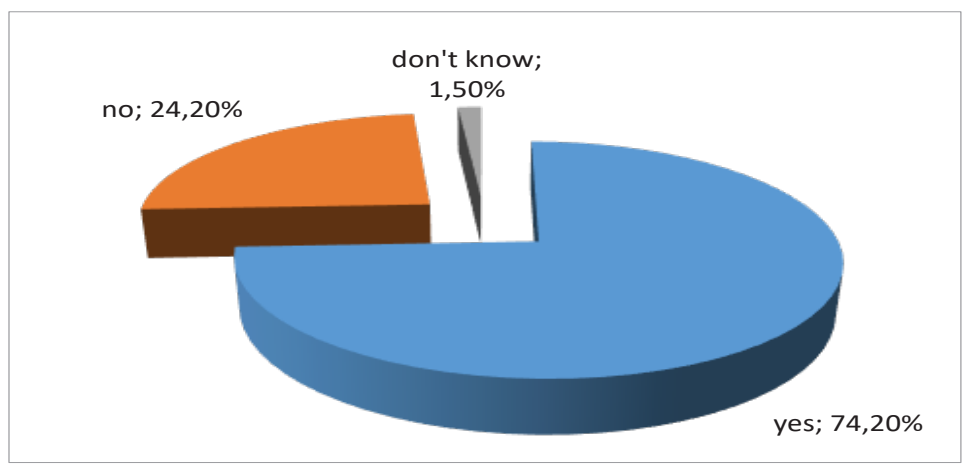

Fig. 2. Answers to the question: is your residential district comfortable for living?

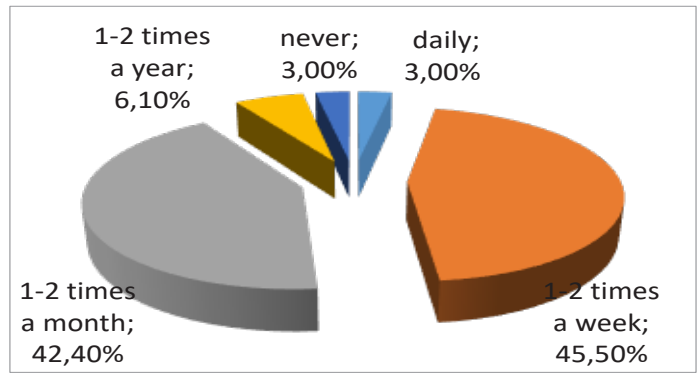

Fig. 3. Answers to the question: how often do you visit public recreation areas: parks, squares, embankments, etc.?

In their responses whether they are satisfied with the recreation areas, only $28.8 \%$ of respondents expressed their satisfaction. Those who were not completely satisfied with the existing recreation areas specified the following inconveniences (Table 2).

Table 2. Distribution of responses on what is particularly unsatisfactory in the existing recreation areas.

\begin{tabular}{|l|c|}
\hline \multicolumn{1}{|c|}{ Answer } & $\begin{array}{c}\text { Share of those who specified } \\
\text { what they are unsatisfied with }\end{array}$ \\
\hline Lack of hygienic conditions (public facilities, toilets) & $43.9 \%$ \\
\hline $\begin{array}{l}\text { Lack of or insufficient entertainment services (games, roller } \\
\text { skating, bicycles, amusements) }\end{array}$ & $40.9 \%$ \\
\hline Lack of parking spots & $19.7 \%$ \\
\hline Lack of space (small territory) & $19.7 \%$ \\
\hline Lack of catering services & $16.7 \%$ \\
\hline Noise & $15.2 \%$ \\
\hline Lack of transport accessibility & $6.1 \%$ \\
\hline Other (not specified) & $18.2 \%$ \\
\hline
\end{tabular}




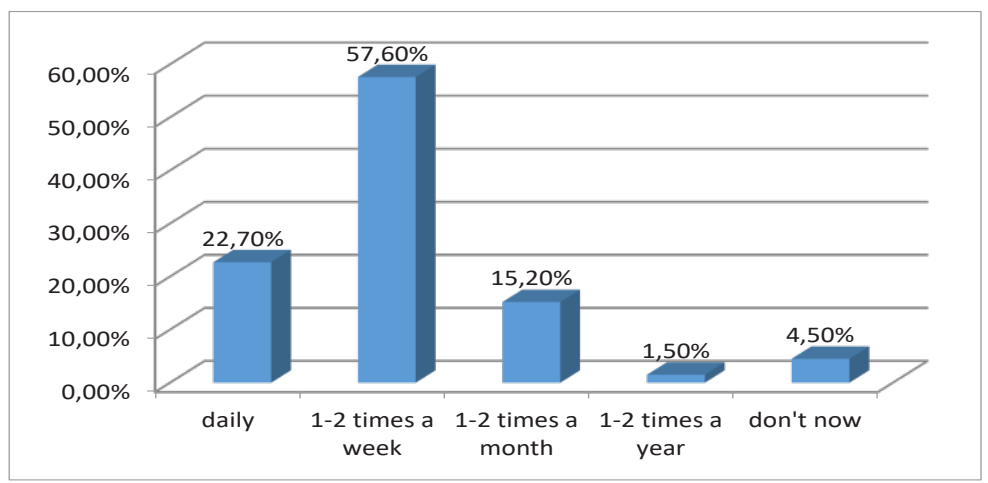

Fig. 4. Answers to the question: if the specified drawbacks are improved, how often would you visit the recreation areas?

Table 3. Change in demand of recreation services after improvement of drawbacks.

\begin{tabular}{|l|c|c|}
\hline \multirow{2}{*}{ Attendance of recreation areas } & \multicolumn{2}{|c|}{ Share of those who responded } \\
\cline { 2 - 3 } & Before improvement & After improvement \\
\hline Daily & $3 \%$ & $22.7 \%$ \\
\hline Once or twice a week & $45.5 \%$ & $57.6 \%$ \\
\hline Once or twice a month & $42.4 \%$ & $15.2 \%$ \\
\hline Once or twice a year & $6.1 \%$ & $1.5 \%$ \\
\hline Never & $3 \%$ & - \\
\hline I don't know & - & $4.5 \%$ \\
\hline
\end{tabular}

According to Table 3, in case the existing recreation areas are improved, the demand in recreation services among the local residents will be much higher.

In order to analyze the level of satisfaction of local residents' need in recreation the respondents were asked what kind of recreation areas lack in the city. The results of the survey are presented in Figure 5. The diagram demonstrates that the majority of respondents emphasized the lack of multifunctional objects, which indicates a variety of recreation preferences of the locals.

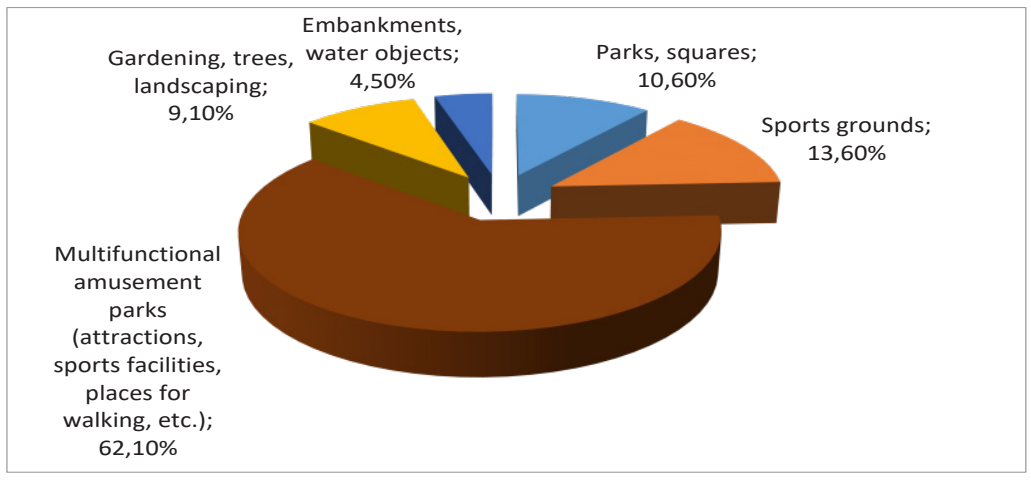

Fig. 5. Answers to the question: what kind of recreation areas lack in Tomsk?

Public micro-areas have special importance in the urban environment, since they provide daily recreation to all groups of residents. This problem is mostly relevant for 
Russian cities with high share of multi-family residential buildings. This category of housing represents $75.8 \%$ of all residential housing in Russia, $65.2 \%$ of population reside here (calculated by the authors based on $[10,11]$ ). Whereas in European countries a smaller share of population lives in apartments. For example, in Norway the share of apartment housing is $13.4 \%$, in the UK - $14.5 \%$, in Belgium - $25.1 \%$, in the Netherlands - $29 \%$ [12]. In these countries daily recreation is performed in micro-areas - household territories. Those Russian citizens who live in apartments carry out their daily recreation in public micro-areas located between the buildings in residential areas.

As a result of the conducted sociological survey the authors found that more that $75 \%$ of the respondents are unsatisfied with the quality of public micro-areas, whereas $62.5 \%$ emphasized the lack of playgrounds, sports facilities and recreation areas for adults in their courtyards. And only $25 \%$ replied that they are completely satisfied with their neighborhood areas.

Visual inspection of courtyard areas in one of Tomsk residential districts was performed for more detailed analysis of the reasons for poor satisfaction level among local residents. The analyzed recreation micro-areas are located on a map and presented in Figure 6. The study showed that out of the 21 analyzed areas in the studied residential district, only one third of courtyard zones meet the needs of the residents in daily recreation.

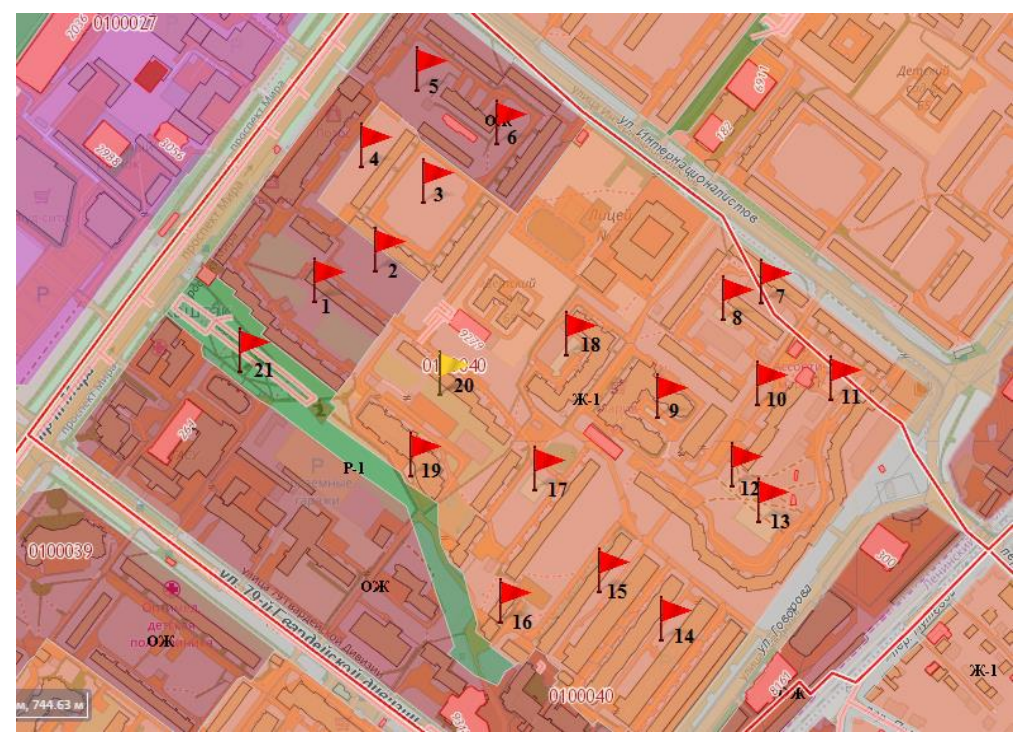

Fig. 6. The analyzed recreation micro-areas located in a residential district of Tomsk.

\section{Conclusion}

The performed research confirms the importance of public recreation areas in the urban environment as a factor for human capital renovation. At the same time, the results of the study show that the recreation needs of the residents, particularly need in daily recreation, are not fully satisfied.

On the basis of visual inspection of the existing recreation micro-areas in one of the residential districts the complex of recommendations was developed for their improvement. It also allowed defining the volume and scope of work and assessing the required investments for creation of appropriate recreation micro-areas in the urban environment. With regard to different technical condition of equipment and street furniture in the courtyard areas, the amount of investments required for these courtyards is about $\$ 250,000$, 
with the average of $\$ 12,000$ per courtyard. The results were obtained on the example of one residential district, but they can be extrapolated on all urban space. This will enable to perform urban planning with the account of "City Recreation" concept.

\section{References}

1. The Human Capital Report (World Economic Forum, Cologny/Geneva 2013)

2. The Human Capital Report (World Economic Forum, Cologny/Geneva 2015)

3. T. Ovsiannikova, M. Nikolaenko, AIP Conf. Proc. 1800 (2016)

4. A. Hauge, Architectural Science Review (2007)

5. Ministerstvo stroitel'stva i zhilishchno-kommunal'nogo khozyaistva Rossiiskoi Federatsii, Available at: http://www.minstroyrf.ru/trades/zhilishno-kommunalnoehozyajstvo/strategicheskoe-napravlenie-razvitiya-zhkkh-i-gorodskaya-sreda (2017)

6. V. Yanchenkov, N. Shagov, Vestnik of TSUAB, 1, 100 (2011) (in Russian)

7. V. Yanchenkov, N. Shagov, Vestnik of TSUAB. English version appendix, 1 (2012)

8. State of the world's cities 2012/2013. Prosperity of cities, United Nations Human Settlements Programme (UN-HABITAT, Nairobi, 2015)

9. Official data on population of Tomskstat, available at: http://msk.gks.ru/wps/wcm/connect/rosstat_ts/tmsk/ru/statistics/population/ (2017) (in Russian)

10. Zhilishchnoe khozyaistvo v Rossii [Housing in Russia] (Rosstat, 2013) (in Russian)

11. Results of the All-Russian population census 2010, Book 9. Living conditions of the population (Rosstat, 2017) (in Russian)

12. Living Conditions in Europe (Eurostat, 2017) 